\title{
Spatial and temporal expression of the period gene in Drosophila melanogaster
}

\author{
Xin Liu, Lori Lorenz, Qiang Yu, Jeffrey C. Hall, and Michael Rosbash \\ Department of Biology, Brandeis University, Waltham, Massachusetts 02254 USA
}

\begin{abstract}
The temporal and spatial expression of the period gene of Drosophila melanogaster has been analyzed by examining the expression of a per $\beta$-galactosidase fusion gene in transformants and by in situ hybridization experiments with wild-type flies. Several strains of Drosophila melanogaster, transformed with the fusion gene, have been generated. The gene is active in mid-late embryos in the midline of the nervous system. Thereafter, $\beta$-galactosidase activity is undetectable until the pupal stage when the prothoracic gland-corpora allata and the optic lobes are $\beta$-galactosidase positive. In adults a surprisingly large number of tissues stain positively, including antennae, proboscis, eyes, optic lobes, cells of the central brain, cells of the thoracic ganglia, gut, Malpighian tubules, and ovarian follicle cells. The temporal pattern of expression agrees well with previous estimates made from developmental Northern blots with RNA extracted from wild-type animals. We suggest that many of the tissues that express the per gene contain their own intrinsic oscillator activity.
\end{abstract}

[Key Words: per; $\beta$-galactosidase fusion; Drosophila; rhythms]

Received October 8, 1987; revised version accepted December 16, 1987.

Biological rhythms are ubiquitous features of eukaryotes. Although rhythms, and in particular circadian rhythms, have been objects of study for a long time in mammals, birds, insects (Saunders 1982), and microbial organisms, almost nothing is known about the molecular mechanisms at their base.

We have been interested in these phenomena in the fruit fly, Drosophila melanogaster, in part because of the genetic tools available in this organism. Indeed, there exist a number of loci which, when mutant, alter or seemingly eliminate Drosophila's biological clocks (for review, see Hall and Rosbash 1987). Of these loci, the best studied is the period gene (per) on the X chromosome (Konopka and Benzer 1971). Mutant alleles of the per locus exist which shorten, lengthen, or apparently eliminate circadian rhythms. These alleles have a similar effect on a more recently described short-term /ultradian) rhythm associated with the male courtship song (Kyriacou and Hall 1980). An interpretation of these observations is that the per gene product is a component of, or influences, the ultradian courtship clock in a manner not unlike its effect on the circadian clock.

In addition to analysis of effects of mutant alleles at the per locus, this gene has also been extensively studied at the molecular level. The gene has been cloned, identified by transformation and functional in vivo assays, and sequenced (Bargiello and Young 1984; Bargiello et al. 1984; Reddy et al. 1984; Zehring et al. 1984; Hamblen et al. 1986; Jackson et al. 1986; Citri et al. 1987). In conjunction with transcript analysis and cDNA sequencing, the data indicate that the per gene codes for a major primary translation prorduct of 1218 amino acids as well as at least two minor variants generated by alternate splicing (Jackson et al. 1986; Citri et al. 1987). These observations, and biochemical analyses, have led to the suggestion that per codes for a proteoglycan (Jackson et al. 1986; Reddy et al. 1986; Bargiello et al. 1987). Three of the per mutations alluded to above have been defined as single nucleotide substitutions (Baylies et al. 1987; Yu et al. $1987 \mathrm{~b}$ ). All of the studies done to date support the notion that the $4.5-\mathrm{kb}$ per transcript and its derived polypeptide products are directly relevant to the construction or maintenance of the fly's biological oscillators.

Given the close relationship of the per gene product|s) to the generation of biological rhythms, it is of interest to know, in some detail, the temporal and spatial pattern of per gene expression. Results of this kind might indicate whether the per gene has functions other than those related to rhythmic phenomena. Alternatively or in addition, they might provide answers to a number of questions related to Drosophila's rhythm system. For example, do biological clocks "run" in embryos or larvae? In the adult, is there only a single oscillator in a single location of the nervous system, or are these pacemakers multiple and perhaps present in non-neural as well as neural tissues?

The temporal and spatial pattern of per expression has been previously analyzed at relatively low resolution (James et al. 1986). The results of these developmental Northern blot and in situ hybridization experiments to embryo sections and blot analysis of RNA indicated that the per gene is expressed during mid-late embryogenesis in the nervous system. Subsequently, per expression diminishes until the mid-pupal stage when the abundance of the $4.5-\mathrm{kb}$ transcript increases substantially, after which (late pupae, adults) it remains at a relatively high 
level and is enriched in heads as compared with bodies.

The data presented in this communication concern themselves with a more detailed examination of the temporal and spatial expression of the per gene. We have constructed a per- $\beta$-galactosidase protein fusion (e.g., Mismer and Rubin 1987) which, at least in principle, is under the control of the cis-acting regulatory elements that govern per gene expression. By what are now standard procedures, stable germ line transformants have been generated and analyzed for their pattern of $\beta$-galactosidase expression (cf. Hiromi et al. 1985). The results show an unexpectedly wide array of adult tissues which express the per- $\beta$-galactosidase fusion gene. As control experiments indicate that much if not all of this expression reflects the normal activity of the wild-type per gene, the data lead us to speculate that there are several pacemakers or oscillators widely dispersed among a variety of tissues in the adult fly.

\section{Results}

The per - $\beta$-galactosidase gene fusion construct utilized in these experiments is depicted in Figure 1. The per gene was cleaved at the indicated SacI site, and the $5^{\prime}$ half of the gene unit was fused in frame to the coding region of the E.coli $\beta$-galactosidase gene, which was followed by an SV40 polyadenylation site. All of the differential splicing described previously (Citri et al. 1987) occurs downstream of the SacI site used in this construction, suggesting that $\beta$-galactosidase expression should be insensitive to these splicing differences. This construction contains all of the $5^{\prime}$-flanking DNA present in a 13.2-kb wild-type per gene-containing DNA fragment, which almost completely rescues all of the effects of arrhythmic per mutations (Citri et al. 1987; Yu et al. 1987a). In principle, this fusion also carries approximately $50 \%$ (630 amino acids) of the per protein upstream of the $\beta$-galactosidase coding unit (Citri et al. 1987). By screening for rosy ${ }^{+}$descendants of the embryos injected with this vector, four independent transformed lines were generated. From these lines, animals at various stages of development were assayed for $\beta$-galactosidase expression by a variety of procedures.

The expression of the per- $\beta$-galactosidase fusion in whole mount embryos, stained with the chromogenic substrate X-gal, is shown in Figure 2. In a mixed population of embryos, no staining is visible before stage 14 (Fig. 2A). This corresponds to approximately $11 \mathrm{hr}$ of embryogenesis (Campos-Ortega and Hartenstein 1985). This staining pattern is in reasonably good agreement with the developmental analysis of per RNA expression previously described (James et al. 1986). The staining is discontinuous and suggests a set of metameric repeating structures within which per is expressed. Indeed, 13 knobs or staining units are visible, consistent with the known number of individual head, thoracic, and abdominal ganglia. The staining remains relatively constant in intensity throughout the remainder of embryogenesis as the nervous system contracts (Fig. 2B). No specific staining was ever visible in control, untransformed embryos.

Recent in situ hybridization experiments, using RNA probes and paraffin sections (see Methods and materials), showed a clear per-specific signal associated with the embryonic central nervous system and brain (data not shown). Noteworthy is the fact that the spatial and tem-

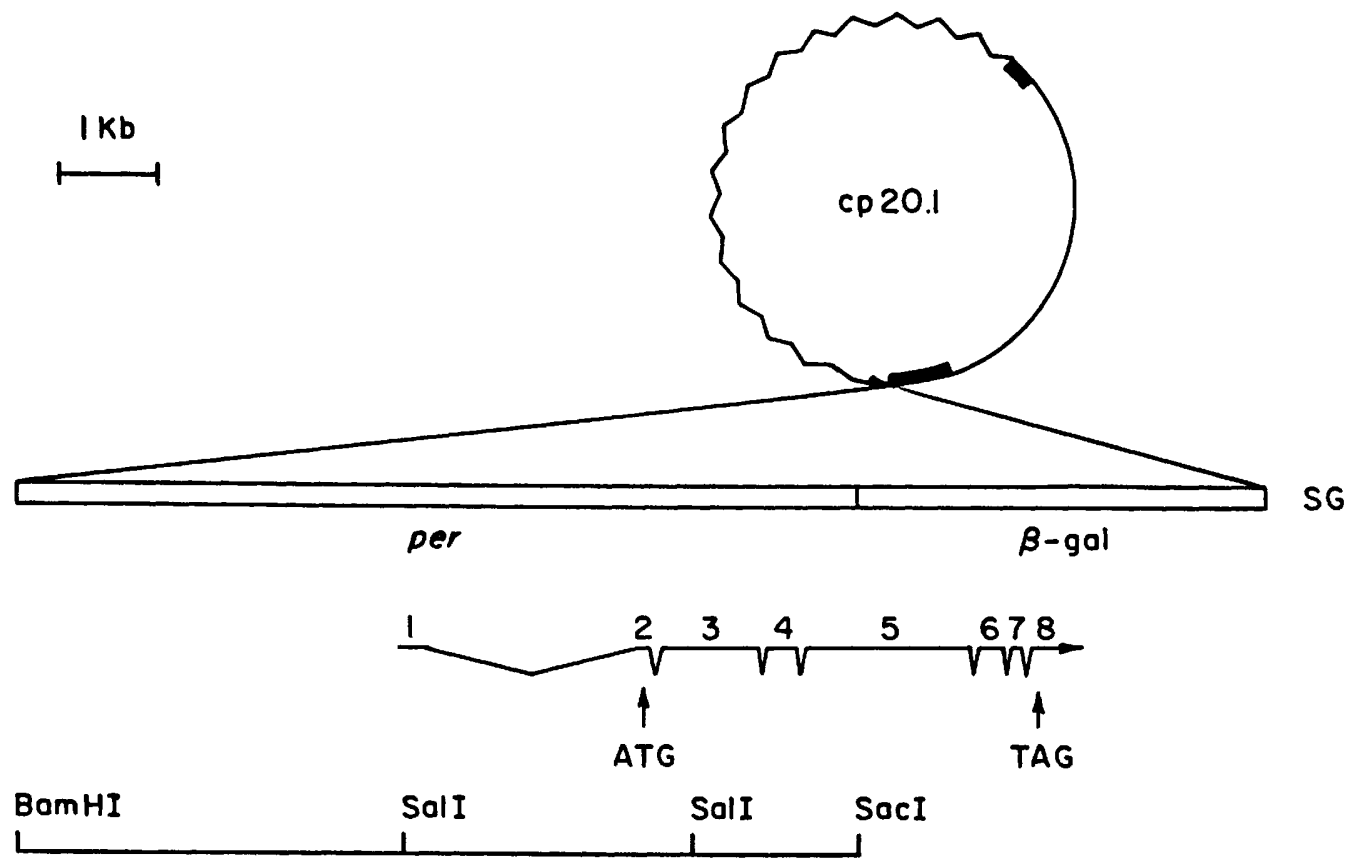

Figure 1. Fusion gene construct. The fusion gene, constructed as described in Materials and methods, is diagrammed. 

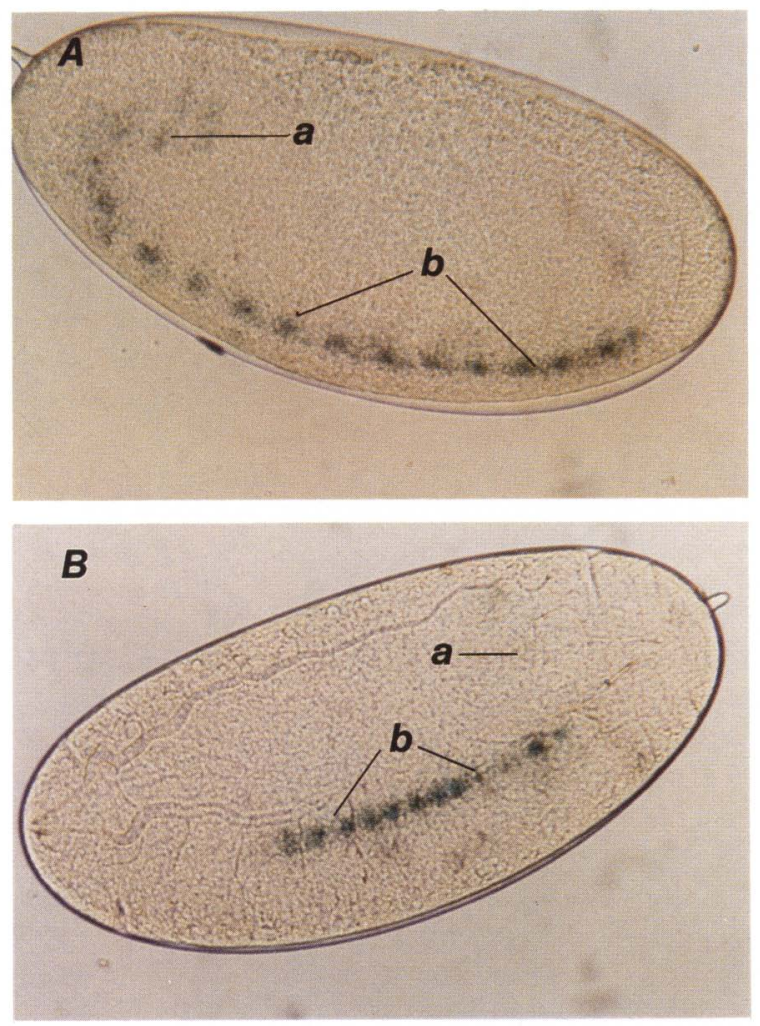

Figure 2. Embryonic expression of the fusion gene. Bright-field micrographs of whole mount embryos from a per- $\beta$-galactosidase transformant strain, stained with X-gal. $(A)$ An embryo, about $11.5 \mathrm{hr}$ old (stage 14). Head (a) and ventral cord (b). In the ventral cord, there are 13 knobs which can be counted. They are (anterior to posterior) mandibular bud, maxillar bud, and labial bud (visible together as only two knobs); $\mathrm{Tl}-3$; and $\mathrm{Al}-8$. The anterior of the embryo is to the left. (B) An embryo, about $18 \mathrm{hr}$ old (stage 17). Head (a) and ventral cord (b) are stained blue (head is difficult to see in photograph). The anterior of the embryo is to the right. The identification of the stages and structures is based on Campos-Ortega and Hartenstein (1985).

poral pattern of per RNA expression is identical to the $\beta$-galactosidase expression pattern (Fig. 2); these results agree with those previously obtained by developmental Northern blot analysis and by in situ hybridization using DNA probes and frozen sections (James et al. 1986).

$\beta$-Galactosidase staining is undetectable during the larval stages, by staining of frozen sections of first, second, and third instar larvae (with very faint staining of the nervous system detectable in first instar larvae) and by staining of whole mounts of dissected third larval salivary glands (data not shown). These results are surprising in light of the per salivary gland expression observed by Bargiello et al. (1987). During the early pupal stage, there is an increase in $\beta$-galactosidase staining of the abdomen, but it is difficult to identify the stained tissues (data not shown). During the mid-to-late pupal stages, a recognizable pattern begins to emerge (Fig. 3). At this time, the most intensely stained structures are the ring gland (corpora allata-prothoracic gland complex) and the optic lobes, most notably the medulla and, to a lesser extent, the lamina (Fig. 3A). The staining of the optic lobes is difficult to assign to precise cells or groups of cells because, at this stage, the staining is quite
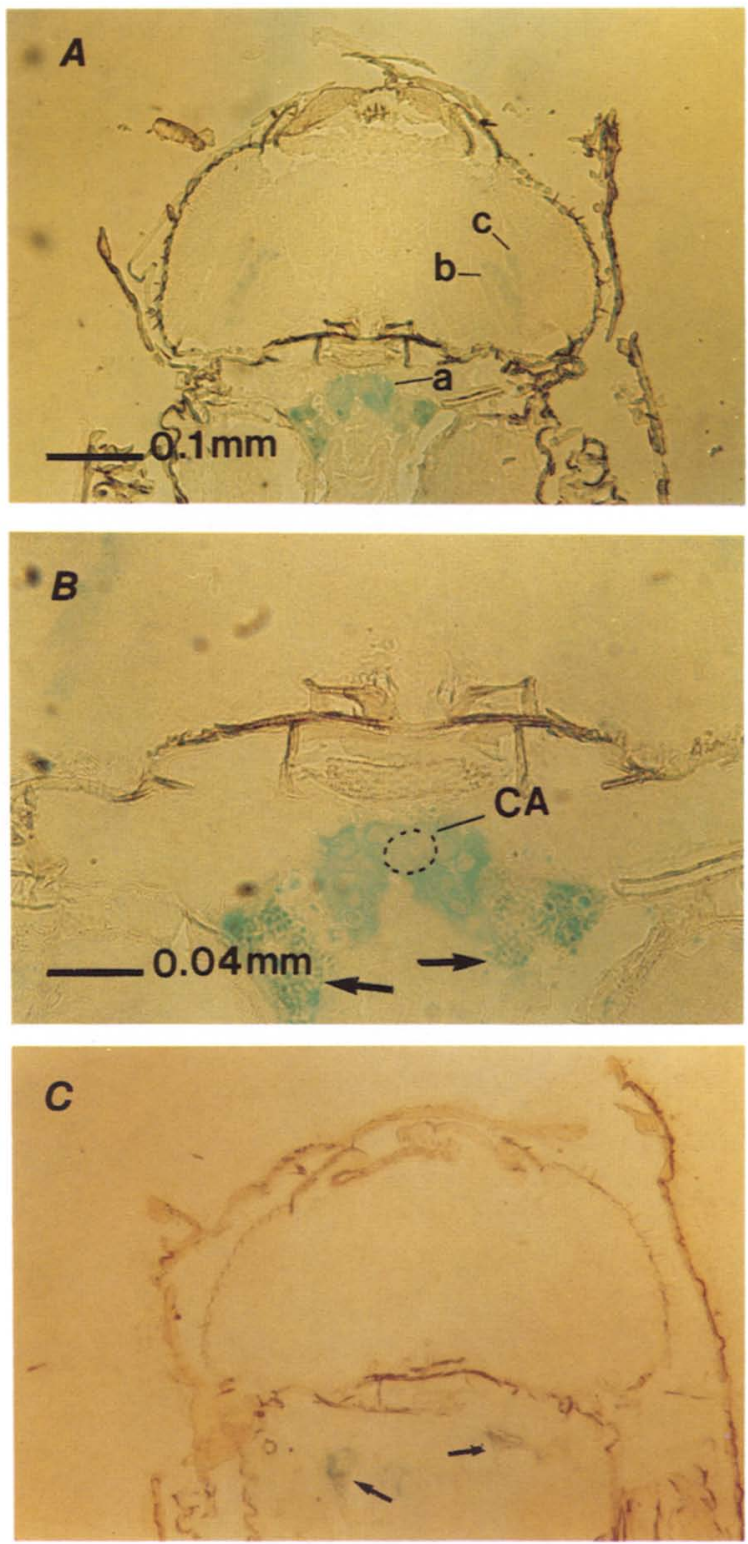

Figure 3. Fusion gene expression at the pupal stage. Brightfield micrographs of sections stained with X-gal. $(A)$ The head and the anterior part of the thorax of an $\sim 72$-hr-old pupa, from a per- $\beta$-galactosidase transformant. Ring gland (a), medulla (b), and lamina (c) and stained blue. $(B)$ A closer view of the ring gland. In the center (the dashed circle) of the ring gland is the corpus allatum (CA) which is composed of small cells. On both sides of the CA are large prothoracic gland cells. Arrows point to some nonspecific staining (i.e., present in the control), possibly in the trachea. $(C)$ Control. The head and the anterior part of the thorax from an $\sim 72$-hr-old pupa from a per ${ }^{01} \mathrm{ry}^{506}$ strain. Only the trachea is stained (arrows). The identification of the stages and structures is based on Bodenstein (1965). 

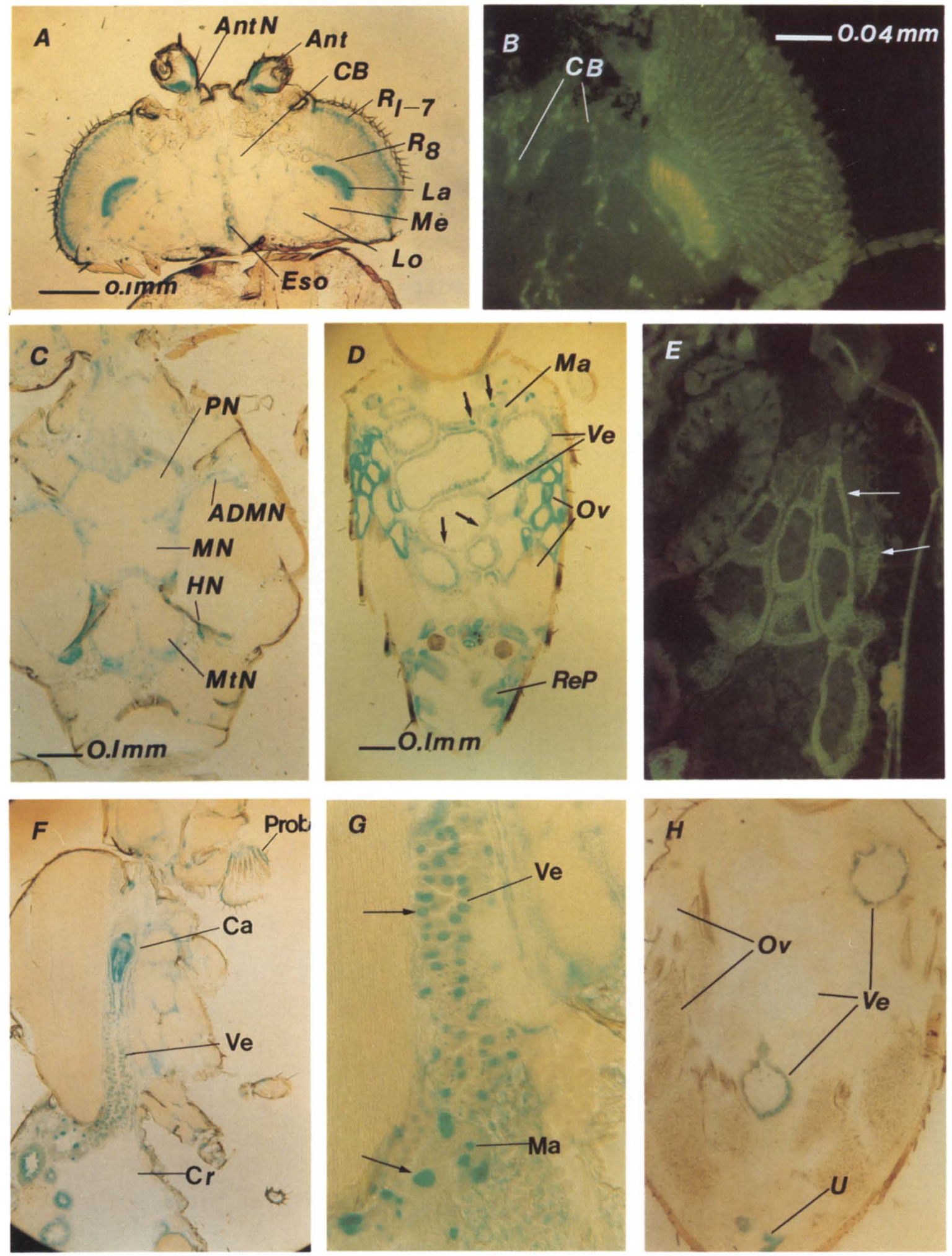

Figure 4. (See following page for legend.) 
diffuse by comparison with that seen in the optic lobes of adults (Fig. 4A and see below). Likewise, staining of the ring gland is also quite diffuse (Fig. $4 \mathrm{~B}$ ). The $\beta$-galactosidase activity flanking the ring gland is probably due to the trachea and is nonspecific, in that it is similarly present in wild-type, nontransformed control flies (Fig. $4 \mathrm{Cl}$.

In the adult head, a remarkable collection of cells and tissues stain positively for $\beta$-galactosidase (Fig. 4). The eyes, optic lobes, antennae, ocelli (data not shown), central brain, proboscis (Fig. 4F), and esophagus all stain positively for $\beta$-galactosidase. None of these cells or tissues stain in the control, i.e., all are completely negative when control (wild-type, nontransformed) flies are processed and stained in an identical fashion (data not shown).

For the eye, it appears that the photoreceptor cells stain positively for $\beta$-galactosidase (Fig. 4A,B). Although the data shown do not support a strong conclusion insofar as the R1-R7 photoreceptor cells are concerned [since other cells are present in the distal region of the eye (e.g., Pak 1975)], the staining of sagittal sections suggests that it is the photoreceptor cells (at least R1-R6) which express $\beta$-galactosidase in the distal region of the eyes (data not shown). Also, the proximal line of cells coincides well with the described position of R8 (Pak 1975). Staining in the photoreceptor layer seemed most intense in the nuclei or perinuclear region of these eye cells (see Fig. 4B, legend). While staining is the most intense in this area, it is not restricted to the perinuclear region: The entire length of the photoreceptor layer was stained in that the region between R1-R7 and R8 nuclei took on a blue, speckled appearance. The origin or significance of this staining is unclear, as it may reflect per product synthesis in, or transport to, these more proximal regions of photoreceptor cell bodies. Alternatively, it may represent artifactual synthesis or transport of $\beta$ galactosidase in these regions.

Cell bodies associated with the optic lobes are a second, intense site of $\beta$-galactosidase staining. Most prominent are $\mathrm{R} 1-\mathrm{R} 6$ cartridges or a subset of lamina cell bodies, probably epithelial glial cell bodies, located close to the outer surface of the lamina (Strausfeld 1976). These are the most intense staining regions of the lamina, and may be the source of the less intense staining elsewhere in the lamina. Also clearly visible is a row of cell bodies that lie between the lamina and the medulla. In fact, stained cell bodies are visible between all of the defined structures of the optic lobes, i.e., between the lamina and the medulla, between the medulla and the lobula, between the lobula and the lobula plate, and between the optic lobe and the central brain.

The staining of the antennae appears associated with sensory cells, while that associated with the ocelli has not been defined (data not shown). The staining of the esophagus is also intense, and appears associated with nuclei or the nuclear region (also, see below). A number of cells stain in the central brain (Fig. 4B). As in the eye, this central brain staining appears nuclear or perinuclear. Staining is visible in the cortex and within neuropil regions, in the latter case perhaps from glial cells.

Moving in a posterior direction, there is clear but less intense staining associated with thoracic appendages (halteres, legs) and with the thoracic and abdominal ganglia of the adult central nervous system (Fig. 4C). The staining is present in regions of the ganglia which contain cell bodies, but for unknown reasons appears less localized, i.e., more diffuse, than the staining shown above for the neurons in the head. The thoracic nervous system staining in some cases continues to the periphery where the nerves make connections to nonneural structures (data not shown).

In the adbomen (Fig. 4D) there is a surprisingly rich array of tissues that are $\beta$-galactosidase positive. The follicle cells associated with small previtellogenic egg chambers stain intensely for $\beta$-galactosidase (Fig. $4 D, E)$. The staining in this tissue appears associated with the cytoplasm, and/or membranes, and/or extracellular matrix. This staining disappears as the egg chambers mature so that the larger and more proximal

Figure 4. Fusion gene expression in adult flies. $(A-G)$ Sections of transformant strain. $(H)$ Section of wild-type strain. $(A, C, D, F-H)$ Bright-field micrographs of adult sections stained with X-gal. $(B, E)$ Fluorescent micrographs of adult sections from the transformant strain stained with a mouse anti- $\beta$-galactosidase antibody as in Materials and methods. All transformant flies have a single copy of the fusion gene in their genome. (A) Horizontal section of the head from an adult female. Eye: (R1-R7) putatively, nuclear region of distal photoreceptor cells; (R8) nuclear region of proximal photoreceptor cells. (La) Lamina; (Me) medulla; (Lo) lobula and lobula plate; (CB) central brain; (Eso) esophagus; (Ant) antenna; (AntN) antenna nerve. (B) Horizontal section of the head from an adult female, at higher magnification. $(\mathrm{CB})$ Central brain cell staining, which also appears nuclear or perinuclear. $(C)$ Horizontal section of the thorax from a female fly. (ADMN) Anterior dorsal mesothoracic nerve; (HN) haltere nerve or dorsal metathoracic nerve; (MN) mesothoracic neuromere; (MtN) metathoracic neuromere; (PN) prothoracic neuromere. (D) Horizontal section of the abdomen from an adult female. (Ve) Ventriculus; arrows point to the cells in the ventriculus which stain positive. (Ma) Malpighian tubule; arrows point to the nuclear region of the epithelial cells in the Malpighian tubule. $(\mathrm{Ov})$ Ovary; $(\mathrm{ReP})$ rectal papillae. $(E)$ Horizontal section of the abdomen from an adult female, at higher magnification. Arrows point to the cube-shaped follicle cells which, given a doughnut appearance, are stained in the cytoplasmic and/or peri-cell membrane regions. $(F)$ Vertical longitudinal section of the head and thorax from an adult male. (Prob) Proboscis; (Ca) cardia; (Ve) thoracic ventriculus (thoracic part); (Cr) crop. (G) Higher-magnification micrograph of a vertical longitudinal section of part of the thorax and abdomen. (Ve) Ventriculus; (Ma) Malpighian tubule. Arrows point to the nuclear region. (H) Control. A horizontal section of the abdomen from a wild-type adult. (Ve) Ventriculus; (U) uterus; (Ov) ovary. (Compare with G.) The identification of the structures is based on Bodenstein (1965) and Kankel et al. (1980). 

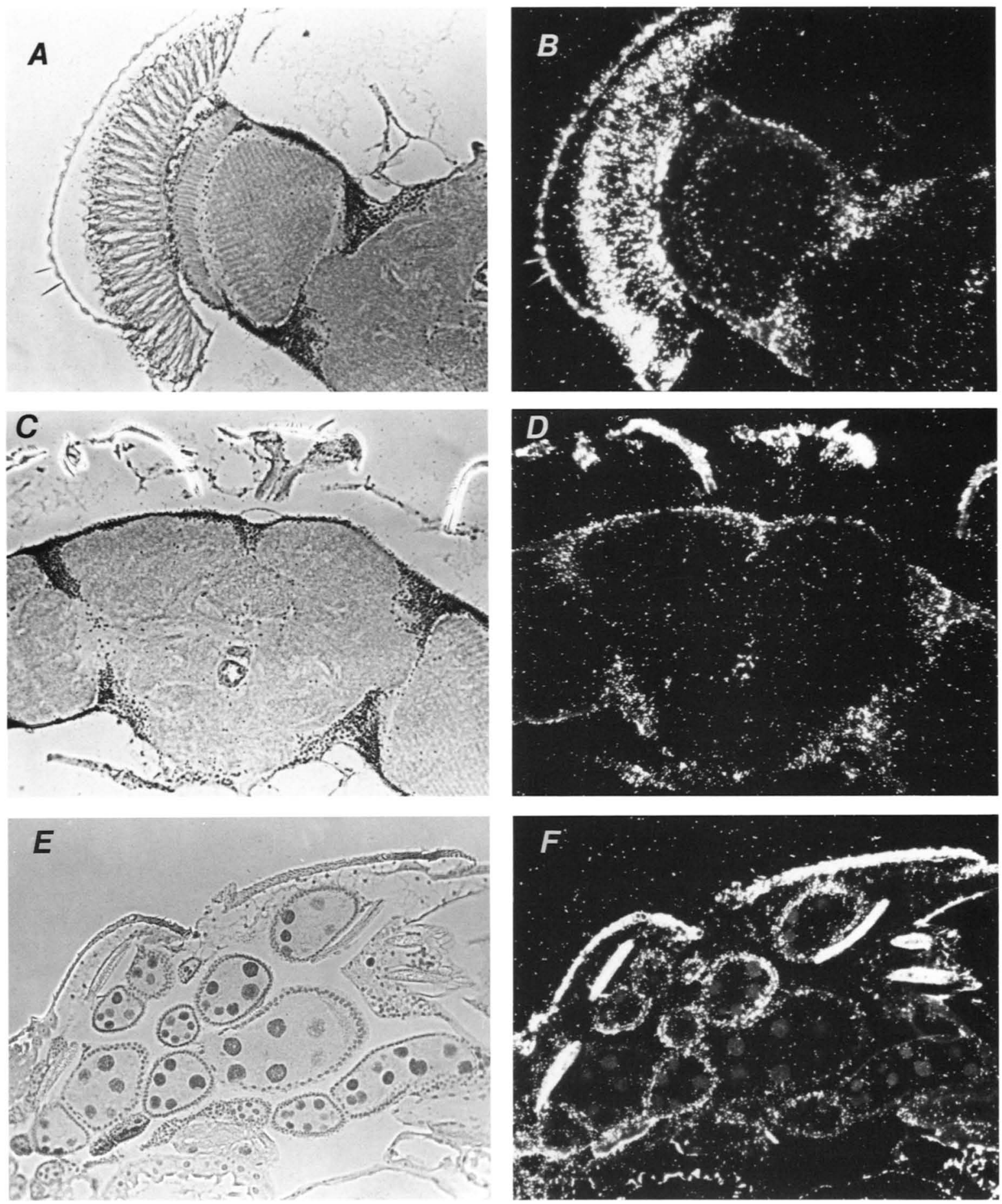

Figure 5. Spatial expression of per RNA in adult flies. One-to-two-week-old wild-type (Canton S) and per- $(D f(1) T E M 202 / D f(1) 64 j 4)$ females were sectioned, hybridized to an [ $\left.{ }^{35} S\right]$ RNA probe specific for per (see Materials and methods) and covered with emulsion. Tissues were stained with hematoxylin. $(A, C, E)$ Phase contrast. $(B, D, F)$ Dark field. $(A, B)$ Transverse section through the eye and optic lobe of a wild-type fly. Localized hybridization is apparent over the outer and inner regions of the eye and over areas that contain the neuronal cell bodies (seen by the darkly staining nuclei) around and within the optic lobe. Such hybridization patterns are not obtained when a similar section of a per- head is probed (data not shown). $(C, D)$ Central brain and ocelli photographed from the same section as $A$ and $B$. Silver grains are localized to the cells bodies surrounding the neuropil of the central brain and to the neurons at the bases of the ocelli. $(E, F)$ Pattern of per expression in follicle cells which surround immature egg chambers in wild-type female ovaries. Hybridization is less evident around older (larger) chambers. Magnifications: $(A, B) 897 \times ;(C, D) 910 \times ;(E, F) 858 \times$. 
ones no longer stain positively. Also staining in the abdomen are a number of other structures, including the gut, Malpighian tubules, and rectum, all of which are principally epithelial cells (Fig. 4D). Although some staining of the inner surface of the midgut is apparent in control animals (Fig. 4H), the gut staining shown in Figure 4 (and in particular the nuclear or perinuclear localization of the gut staining shown in Fig. $4 \mathrm{~F}$ and $4 \mathrm{G}$ ) is completely specific to the transformant strains.

In situ hybridization to adult wild-type flies reveals per RNA at the major sites of expression as defined by the $\beta$-galactosidase assays on the transformant strains. Visible in Figure 5 is a specific signal in the eye and in many of the cell bodies associated with the optic lobes (Fig. 5A,B), central brain, and ocelli (Fig. 5C,D). No specific signal is detectable in heads of mutant adults which are homozygous for a deletion of the per locus (data not shown). Cell bodies surrounding the thoracic and abdominal ganglia also show a specific hybridization signal (data not shown). The follicle cells of the young egg chambers clearly express per RNA (Fig. 5E,F), and no signal is detected when per- animals are assayed (data not shown). Like the $\beta$-galactosidase staining, the specific RNA signal is no longer detectable in the follicle cells of more mature egg chambers. In situ hybridization produces a strong signal in the other major $\beta$-galactosidase-positive abdominal tissues (gut, esophagus, Malpighian tubules, salivary glands, rectal papillae, male and female reproductive systems). However, the level of nonspecific background (apparent hybridization to per $^{-}$ animals) precludes assignment of a specific signal to these adult tissues (data not shown).

\section{Discussion}

We have generated four independent transformed lines of the fusion gene depicted in Figure 1. Although most of the results have been obtained by analyzing a single line, all of the major conclusions have been verified by examining in detail at least one other line. Also, a second fusion gene construct was generated identical to the construct shown in Figure 1 except that this second construct contains 829 , as opposed to 630 , amino acids of the per coding region upstream of the $\beta$-galactosidase coding region. A cursory examination of $\beta$-galactosidase expression in one transformed line carrying this second construct revealed a pattern qualitatively similar to that described for the lines derived from the construct in Figure 1.

The fusion gene manifests no biolgical activity, as it is unable to rescue the arrhythmic behavior of $p e r^{0}$ animals. Neither does it show any biological activity by an interference assay, as the rhythmic behavior of wild-type animals is unaffected by the presence of the fusion gene (data not shown, and see Materials and methods). In a complementary fashion, the activity of the fusion gene (as assayed by $\beta$-galactosidase staining) is unaffected by per expression, as per ${ }^{0}$ and $p e r^{+}$animals which carry the fusion gene stain identically (data not shown).

The observed embryo nervous system expression coin- cides well with our previous in situ hybridization study and developmental Northern blot analysis (James et al. 1986). The experiments reported here clearly show per RNA along the ventral midline of the embryo central nervous system, a region known to contain unique neuronal cell types (Campos-Ortega and Hartenstein 1985). We note that this is the same general region of the embryonic central nervous system expressing the product of a gene named single-minded (Thomas et al. 1988), a portion of which has primary amino acid sequence homology to the per product/s) (Crews et al. 1988).

We note that neither our previous in situ hybridization study (done with frozen sections and nick-translated DNA probes; James et al. 1986) nor this current $\beta$-galactosidase study shows a significant signal associated with embryonic salivary glands, in contrast to a recent report from another laboratory (Bargiello et al. 1987). Our current in situ studies do show a strong signal from embryonic salivary glands, but the control experiments with a negative-strand probe and an independent probe from another gene also show a comparable signal over embryonic salivary glands /data not shown|. Thus, we are unable to make a definitive statement from our experiments concerning per experession in embryonic salivary glands. If per is highly expressed in salivary glands, it is possible that the fusion gene is missing cis-acting elements (perhaps located 'further' upstream or in the $3^{\prime}$ half of the per gene) required for this salivary gland expression. Alternatively, the fusion gene products may turn over very rapidly in salivary glands, thereby precluding detection by these methods.

The $\beta$-galactosidase activity appears to increase at the mid-pupal stage when stained structures become easy to visualize. This corresponds to the time of mRNA increase as determined by developmental Northern blot analysis (James et al. 1986). The most prominent staining in the heads of pupae is observed in the ring gland (corpora allata and prothoracic gland) and to a lesser extent in the optic lobes. The pupal ring gland-associated signal is of considerable interest because, in other insects and presumably in Drosophila as well (Wigglesworth 1970; Truman 1985), this neurohumoral organ is the site of eclosion hormone release, an event that is "gated" by the circadian clock (Truman 1985). Although we do not yet know what cells in the ring gland contain $\beta$-galactosidase (the staining is particularly diffuse in this organ at this time), the relationship between the $\beta$-galactosidase-positive cells and the eclosion hormone-positive neurosecretory cells known in other insects (Copenhaver and Truman 1986) should prove to be interesting.

Staining in the corpus allatum and the optic lobe persists and increases in intensity (especially in the latter case) in the adult. Indeed, the eye and optic lobes are the most prominent (but not the exclusive) sites of per expression in the head (Fig. 4). Numerous cells in the central brain also stain positively for $\beta$-galactosidase. In conjunction with all of the numerous non-neural cells and tissues that also express the fusion gene, we infer that the per gene is very widely expressed. To what ex- 
tent is the expression of the fusion gene a quantitatively and qualitatively reliable indicator of per gene expression?

From the quantitative point of view, we suspect that the relative intensity of the $\beta$-galactosidase staining in the various adult tissues may reflect the relative levels of per expression, at least at the RNA level. For example, the in situ hybridization signal associated with the eye and lamina is more intense than what is observed in the central brain (Fig. 5), consistent with the staining results (Fig. 4A). Also, the fusion gene manifests dosage compensation as might be expected for an X-linked gene. Male flies that carry a single copy of the fusion gene show an increased signal compared with single-dosebearing females, suggesting that the left half of the per gene carries a functional, cis-acting, dosage-compensating element (data not shown). This observation is similar to the effect of the $13.2-\mathrm{kb}$ per gene-containing DNA fragment, a single dose of which provides males with a slightly shorter rhythm (indicating higher expression; cf. Smith and Konopka 1982; Coté and Brody 1986; Baylies et al. 1987) than that of females that carry a single dose (Citri et al. 1987).

From a qualitative point of view, we believe that the adult tissue assignments, made on the basis of $\beta$-galactosidase staining, are largely correct. However, there may be some adult cells or tissues that stain inappropriately, and other cells or tissues that fail to stain despite per gene expression. The in situ hybridization experiments presented here reinforce some of the conclusions from the $\beta$-galactosidase staining, but they are limited in sensitivity, especially in the adult where many tissues show considerable nonspecific (per- animals) signal. Recent work in this laboratory with an anti-per antibody also suggests that many of these $\beta$-galactosidase-positive tissues are per protein-positive in wild-type adults $(\mathrm{K}$. Siwicki, pers. comm.). The eye, optic lobes, defined cells in the central brain, and those in the gut all stain positively by this assay, suggesting that the $\beta$-galactosidase pattern in the transformants reflects, at least in part, the per protein pattern in wild-type animals.

What do these expression studies tell us about the function(s) of the per gene products and the location of biological oscillators? From the point of view of function, these data shed little light on this issue; we do note, however, that many of the positive tissues are epithelia and appear to stain uniformly. These two observations are consistent with the notion that at least one function of the per protein may be to regulate gap junctions (Bargiello et al. 1987). From the point of view of oscillator location, there is genetic evidence from Drosophila that the per gene manifests its effect on locomotor activity rhythms from the head (Konopka et al. 1983). There is also a report that salivary glands manifest intrinsic oscillator activity /Weitzel and Rensing 1981). Additionally, there are experiments with Drosophila as well as other insects that implicate the eye (Williams 1982), optic lobes (Page 1984; Wills et al. 1985), ring gland (Truman 1985), and Malpighian tubules (Friedman and Johnson 1977) as involved in circadian and/or developmental timing phenomena. All of these tissues express the per gene. Based in part on evidence that mammals contain multiple circadian oscillators (Aschoff 1965), we favor the notion that many of these tissues contain intrinsic circadian oscillators which are affected similarly by the per gene product(s). By inference, many of the other adult tissues in which per is expressed may also manifest autonomous or semiautonomous oscillator activity. For example, there is evidence that certain aspects of oogenesis are under circadian control (Allemand 1976, 1977; Fluegel 1981). From the data shown here, we predict that per mutant alleles influence oogenesis and that this effect might be autonomous to the ovaries. Perhaps the gut, ocelli, proboscis, etc., also contain oscillators that generate rhythmic fluctuations relevant to these tissues' functions. From a behavioral analysis of genetic mosaics, we suspect that the short-term courtship rhythm is influenced by the per gene through its expression in the thoracic ganglia (Hall 1984).

An alternative possibility is that some tissues express the per gene gratuitously or that the per gene has different functions in different tissues. The possibility that per may exhibit a different subcellular location in different tissues is consistent with this latter notion. Perhaps the expression of per in embryos reflects a role in embryogenesis somewhat different from its role(s) in adults. In any case, we suggest that the wide tissue distribution of per gene expression reflects the fact that many of these tissues contain their oscillators connected together through neural or humoral pathways which maintain appropriate relationships between the various oscillators. Attempts to test this hypothesis are under way.

\section{Materials and methods}

\section{DNA constructions and transformations}

A per DNA fragment, bordered by a $B a m H I$ site about $4 \mathrm{~kb}$ upstream of the transcription start site and another BamHI site in the fifth exon (Citri et al. 1987), which was in a modified pUCl 8 vector (an XhoI site was in front of the $5^{\prime}$ end of the fragment) was digested with SacI in the fifth exon and SphI (which is after the $3^{\prime}$ end of the fragment in the polylinker). The digestion products were then treated with $\mathrm{T} 4$ polymerase to remove the single-stranded DNA ends and filled in with Klenow to generate blunt ends (Henikoff 1984). A BgIII linker (New England BioLabs, 1001) was ligated to the blunt ends; thus, a new vector containing a per DNA fragment, from the upstream BamHI site to a downstream SacI site followed by a BgIII linker, was created. The junction of the fragment and the BgIII linker was checked by sequencing to make sure that, if the BgIII site was used, this fragment would be ligatable to $E$. coli $\beta$-galactosidase DNA in frame. By BgIII-BamHI ligation this fragment was subcloned to a pUC19 vector (Yanish-Perron et al. 1985 to acquire a KpnI site at the $3^{\prime}$ end. At the same time an EcoRI-EcoRI E. coli $\beta$-galactosidase DNA fragment, purified from pC4 (generously provided by V. Pirotta) was subcloned into a pUCl 8 vector (Yanish-Perron et al. 1985) to create a KpnI site at the $5^{\prime}$ end of this fragment. Finally, the per DNA fragment from the $5^{\prime}$ end $X h o I$ site to the $3^{\prime}$ end $K p n I$ site $(\sim 8.9 \mathrm{~kb})$ 
and the $E$. coli $\beta$-galactosidase DNA fragment from the $5^{\prime}$ end $K p n I$ site to the $3^{\prime}$ end $X b a I$ site $(\sim 4 \mathrm{~kb})$ were purified. They were ligated together at their $K p n I$ sites and inserted into a cp20.1 vector (Simon et al. 1985) at the SalI and XbaI sites. This construction was later used in the transformation. Transformation was performed according to standard methods (Rubin 1985). The independent transformation strains were identified as different from one another by Southern blot analysis and/or chromosomal linkages. Several $\beta$-galactosidase transformants from each strain were examined behaviorally and were arrhythmic. Five $\beta$-galactosidase transformants, in a wild-type background, were also examined behaviorally and were indistinguishable from wild-type flies. In subsequent experiments, transformant strains, a wild-type strain (Canton S), and per $^{01} \mathrm{ry}^{506}$ were all examined for $\beta$-galactosidase activity.

\section{Wholemount staining}

Embryos ranging from 2 to $24 \mathrm{hr}$ after egg laying from a per/ $\beta$ galactosidase transformant strain /whose genetic background was $\mathrm{per}^{01} \mathrm{ry}^{506 \mid}$ and from a Canton $\mathrm{S}$ wild-type control strain were collected. They were treated with $50 \%$ bleach at $25^{\circ} \mathrm{C}$ for $10 \mathrm{~min}$, then washed with water or phosphate-buffered saline (PBS) and treated with heptane at $25^{\circ} \mathrm{C}$ for $25 \mathrm{~min}$. They were washed again with $\mathrm{H}_{2} \mathrm{O}$ or PBS and put into X-gal staining buffer at $37^{\circ} \mathrm{C}$ for 25 to $40 \mathrm{hr}$. Staining buffer: $1 \times \mathrm{PBS}\langle\mathrm{pH} 7.0\rangle$, $20 \mathrm{~mm}$ potassium ferrocyanide, $20 \mathrm{~mm}$ potassium ferricyanide, $0.2 \%$ (wt/vol) X-gal, $10 \% \mathrm{~N}, N$-dimethylformamide, and $1 \mathrm{~mm}$ $\mathrm{MgCl}_{2}$ (Price et al. 1987).

\section{Section staining}

X-gal: Living flies were frozen in Tissue-Tek. The were cut into $14-\mu \mathrm{m}$-thick sections and loaded on gelatin-coated slides. After $\sim 1 \mathrm{hr}$ of air-drying, they were fixed in $0.5 \%$ glutaraldehyde at room temperature for $5 \mathrm{~min}$ and washed in PBS $3 \times 10 \mathrm{~min}$. The sections were submerged in X-gal staining buffer at $37^{\circ} \mathrm{C}$ for 16 $\mathrm{hr}$ and then washed in PBS $3 \times 10 \mathrm{~min}$. The staining buffer is the same as for the whole mounts. They were mounted with 80\% glycerol in PBS. Antibody: Flies were sectioned as for the $\mathrm{X}$-gal staining except that the sections were $10 \mu \mathrm{m}$ thick. After $1 \mathrm{hr}$ of air-drying, they were fixed in $4 \%$ paraformaldehyde on ice for $1 \mathrm{hr}$ and then washed with PBS on ice for $3 \times 10 \mathrm{~min}$. The sections were preincubated with PBST (PBST is PBS $+0.1 \%$ Triton X-100 $+1 \%$ BSA $+0.1 \% \mathrm{NaN}_{3}+1 \%$ glycine) at room temperature for $30 \mathrm{~min}$, then incubated with mouse anti- $\beta$-gal antibody (a gift from C.S. Goodman) in PBST at $4^{\circ} \mathrm{C}$ overnight. The sections were washed with PBS on ice for $3 \times 10 \mathrm{~min}$ and incubated with FITC-conjugated goat antimouse IgG antibody in PBST at $4^{\circ} \mathrm{C}$ overnight. The sections were washed in PBST at room temperature for $3 \times 10 \mathrm{~min}$ and in PBS at room temperature for $1 \times 20 \mathrm{~min}$. They were mounted in the following medium: 1/1000 p-phenylenediamine, $20 \% 20 \mathrm{mM} \mathrm{Na}_{2} \mathrm{CO}_{3}, 80 \%$ glycerol.

\section{In situ hybridization}

Embryos were dechorionated in 3\% sodium hypochlorite for 2 min, washed with $\mathrm{H}_{2} \mathrm{O}$ and fixed in $4 \%$ paraformaldehyde in phosphate-buffered saline (PBS) for $40 \mathrm{~min}$. Vitelline membranes were removed by swirling embryos in heptane/methanol/0.5 M EGTA $(10: 9: 1)$ in a dry ice-ethanol bath, followed by rapid warming to room temperature (Mitchison and Sedat 1983). After rehydration, the embryos were fixed in paraformaldehyde for $15 \mathrm{~min}$ and then dehydrated in a graded ethanol series and xylenes before being embedded in paraffin.

Adults were frozen in dry ice; heads, thoraxes, and abdomens were separated for fixation in paraformaldehyde at $4^{\circ} \mathrm{C}$ overnight (antennae, halteres, and the proboscis are lost during this procedure and thus cannot be scored). The fixed body parts were dehydrated and embedded in paraffin.

Embedded embryos and adults were sectioned $(6 \mu \mathrm{m})$ and mounted onto glass slides coated with $50 \mu \mathrm{g} / \mathrm{ml}$ poly-L-lysine in $10 \mathrm{mM}$ Tris- $\mathrm{HCl}(\mathrm{pH}$ 8). Paraffin was removed with xylenes and the sections were rehydrated. Sections were prepared for hybridization by successive treatments in $0.2 \mathrm{~N} \mathrm{HCl}$ for 20 min, $2 \times \operatorname{SSC}$ ( $\mathrm{SSC}$ is $0.15 \mathrm{M} \mathrm{NaCl}, 0.015 \mathrm{M}$ sodium citrate) at $68^{\circ} \mathrm{C}$ for $30 \mathrm{~min}, 125 \mu \mathrm{g} / \mathrm{ml}$ Pronase in $50 \mathrm{~mm}$ Tris- $\mathrm{HCl} / \mathrm{pH}$ 7.5), $5 \mathrm{~mm}$ EDTA at $37^{\circ} \mathrm{C}$ for $10 \mathrm{~min}$, and $2 \mathrm{mg} / \mathrm{ml}$ glycine in PBS (twice over $1 \mathrm{~min}$ ), with washes in $\mathrm{H}_{2} \mathrm{O}$ in between. The sections then were rinsed in PBS and fixed in paraformaldehyde for $20 \mathrm{~min}$ for visualization of the tissues. The slides were washed in PBS, acetylated in $0.25 \%$ acetic anhydride in $0.1 \mathrm{M}$ triethanolamine ( $\mathrm{pH} 8$ ) for 10 min (Ingham et al. 1985), washed with PBS, and dehydrated.

$\left[{ }^{35} \mathrm{~S}\right]-\mathrm{RNA}$ probes were transcribed from a $1.5-\mathrm{kb}$ BgIII-SstI cDNA fragment encoding per (Citri et al. 1987) using SP6 or T7 transcription systems. (The fragment contains most of the coding region upstream of the Thr-Gly repeat and is from exons 3 to 5.) Control probes consisted of the same fragment in reverse orientation and a probe from the adjacent $0.9-\mathrm{kb}$ cycling RNA (Reddy et al. 1984). The probes were hydrolyzed to $150 \mathrm{bp}$ or less with alkali ( $\mathrm{pH} 10)$ at $60^{\circ} \mathrm{C}$ for $2 \mathrm{hr}$. Sections were hybridized with $0.01-0.1 \mathrm{ng} / \mu \mathrm{l}$ probe in $50 \%$ formamide, $10 \%$ polyethylene glycol, $0.6 \mathrm{M} \mathrm{NaCl}, 10 \mathrm{~mm}$ Tris- $\mathrm{HCl}(\mathrm{pH} 7.5), 10$ mM NaH${ }_{2} \mathrm{PO}_{4} / \mathrm{Na}_{2} \mathrm{HPO}_{4}$ (pH 6.5), 5 mM EDTA, $1 \times$ Denhardt's solution, $20 \mathrm{mM}$ DTT, $500 \mu \mathrm{g} / \mathrm{ml}$ Torula yeast RNA, and $0.1 \%$ SDS at $55^{\circ} \mathrm{C}$ for $6-20 \mathrm{hrs}$. Unhybridized probes were removed by washing in three changes of $50 \%$ formamide, $20 \mathrm{mM} \mathrm{DTT}$, $0.3 \mathrm{M} \mathrm{NaCl}, 10 \mathrm{~mm}$ Tris- $\mathrm{HCl}(\mathrm{pH} 7.5), 10 \mathrm{~mm} \mathrm{NaH} \mathrm{PO}_{4} /$ $\mathrm{Na}_{2} \mathrm{HPO}_{4}$ (pH 6.5), $5 \mathrm{~mm}$ EDTA, $1 \times$ Denhardt's solution, and $0.1 \%$ SDS (wash buffer) at $55^{\circ} \mathrm{C}$ over several hours. Washed sections were digested in $20 \mu \mathrm{g} / \mathrm{ml}$ RNase A in $0.5 \mathrm{M} \mathrm{NaCl}, 10 \mathrm{mM}$ Tris- $\mathrm{HCl}(\mathrm{pH} 8), 1 \mathrm{~mm}$ EDTA (NTE) at $37^{\circ} \mathrm{C}$ for $30 \mathrm{~min}$ and washed with NTE at $37^{\circ} \mathrm{C}$ for $1 \mathrm{hr}$ to reduce nonspecific hybridization. Slides were washed twice in wash buffer at $55^{\circ} \mathrm{C}$ over a few hours. After dehydration, the slides were dipped in Kodak NTB2 emulsion $/ \mathrm{H}_{2} \mathrm{O}(1: 1)$, stored desiccated at $4^{\circ} \mathrm{C}$ for $1-3$ weeks, and developed in Kodak D19 developer. Sections were stained with hematoxylin for visualization of tissue under the microscope.

\section{Acknowledgments}

We thank K. Siwicki for communication of unpublished results and for instruction on sectioning techniques, Hong $\mathrm{Wu}$ for sequencing the per $\beta$-galactosidase junction, $\mathrm{S}$. Robinow and $\mathrm{K}$. White for advice concerning the in situ hybridization experiments, T. Tishman for secretarial assistance, and H.V. Colot for comments on the manuscript. This work was supported by a grant from the National Institutes of Health (GM33205) to J.C.H. and M.R.

\section{Note added in proof}

At the referees' insistence, we have repeated the embryo in situ hybridization experiments of Bargiello et al. (1987), by using the identical per-specific probes employed in their study (kindly provided by M.W. Young and colleagues). With both probes, we obtained the identical results obtained with the more centrally located subclones employed in this study, i.e., an intense salivary gland signal with both the sense and antisense strands, but a less intense nervous system signal with only the antisense strands. 


\section{References}

Allemand, R. 1976. Les rythmes de vitellogenese et d'ovulation en photoperiode LD 12:12 de Drosophila melanogaster. I. Insect Physiol. 22: 1031-1035.

- 1977. Influence de l'intensité d'eclairement sur l'expression du rythme journalier d'ovoposition de Drosophila melanogaster en conditions lumineuses LD 12:12. Comptes Rendus Series D 284: 1553-1556.

Bargiello, T.A. and M.W. Young. 1984. Molecular genetics of a biological clock in Drosophila. Proc. Natl. Acad. Sci. 81: 2142-2146.

Bargiello, T.A., F.R. Jackson, and M.W. Young. 1984. Restoration of circadian behavioural rhythms by gene transfer in Drosophila. Nature 312: 752-754.

Bargiello, T.A., L. Saez, M.K. Baylies, G. Gasic, M.W. Young, and D.C. Spray. 1987. The Drosophila clock gene per affects intercellular junctional communication. Nature 328: 686691.

Baylies, M.K., T.A. Bargiello, F.R. Jackson, and M.W. Young. 1987. Changes in abundance or structure of the per gene product can alter periodicity of the Drosophila clock. $\mathrm{Na}$. ture 326: 390-392.

Bodenstein, D. 1965. The postembryonic development of Drosophila. In Biology of Drosophila (ed. M. Demerec), pp. 275-354. Hafner, New York.

Campos-Ortega, J.A. and V. Hartenstein. 1985. The Embryonic Development of Drosophila melanogaster. Springer-Verlag, Berlin.

Citri, Y., H.V. Colot, A.C. Jacquier, Q. Yu, J.C. Hall, D. Baltimore, and M. Rosbash. 1987. A family of unusually spliced biologically active transcripts encoded by a Drosophila clock gene. Nature 326: 42-47.

Copenhaver, M.P.F. and J.W. Truman. 1986. Identification of the cerebral neurosecretory cells that contain eclosion hormone in the moth Manduca sexta. I. Neurosci. 6: 17381747.

Coté, G.G. and S. Brody. 1986. Circadian rhythms in Drosophila melanogaster: Analysis of period as a function of gene dosage at the per (period) locus. $J$. Theoret. Biol. 121: 487503.

Crews, S.T., J.B. Thomas, and C.S. Goodman. 1988. The Drosophila single-minded gene encodes a nuclear protein with sequence similarity to the per gene product. Cell 52: 143-151.

Fluegel, W. 1981. Oviposition rhythm in Drosophila melanogaster is influenced by acetic acid. I. Insect Physiol. 27: 705-710.

Hall, J.C. 1984. Complex brain and behavioral functions disrupted by mutations in Drosophila. Dev. Genet. 4: 355378.

Hall, J.C. and M. Rosbash. 1987. Genetic and molecular analysis of biological rhythms. J. Biol. Rhythms 2: 153-178.

Hamblen, M., W.A. Zehring, C.P. Kyriacou, P. Reddy, Q. Yu, D.A. Wheeler, L.J. Zwiebel, R.J. Konopka, M. Rosbash, and J.C. Hall. 1986. Germ-line transformation involving DNA from the period locus in Drosophila melanogaster: Overlapping genomic fragments that restore circadian and ultradian rhythmicity to per ${ }^{0}$ and per- mutants. I. Neurogen. 3: 249291.

Handler, A.M. and R.J. Konopka. 1979. Transplantation of a circadian pacemaker in Drosophila. Nature 279: 236-238.

Henikoff, S. 1984. Unidirectional digestion with exonuclease III creates targeted breakpoints for DNA sequencing. Gene 28: 334-359.

Hiromi, Y., A. Kuroiwa, and W.J. Gehring. 1985. Control ele- ments of the Drosophila segmentation gene fushi tarazu. Cell 43: 603-613.

Ingham, P.W., K.R. Howard, and D. Ish-Horowicz. 1985. Transcription pattern of the Drosophila segmentation gene hairy. Nature 318: 439-445.

Jackson, F.R., T.A. Bargiello, S.-H. Yun, and M.W. Young. 1986. Product of per locus of Drosophila shares homology with proteoglycans. Nature 318: 185-188.

James, A.A., J. Ewer, P. Reddy, J.C. Hall, and M. Rosbash. 1986. Embryonic expression of the period clock gene in the central nervous system of Drosophila melanogaster. EMBO. I. 5: $2313-2320$.

Kankel, D.R., A. Ferrus, S.H. Garen, P.J. Harte, and P.E. Lewis. 1980. The structure and development of the nervous system. In The genetics and biology of Drosophila (ed. M. Ashburner and T.R.F. Wright), vol. 2, pp. 295-363. Academic Press, London.

Konopka, R.J. and S. Benzer. 1971. Clock mutants of Drosophila melanogaster. Proc. Nat1. Acad. Sci. 68: 2112-2116.

Konopka, R.J., S. Wells, and T. Lee. 1983. Mosaic analysis of a Drosophila clock mutant. Mol. Gen. Genet. 190: 284-288.

Kyriacou, C.P. and J.C. Hall. 1980. Circadian rhythm mutations in Drosophila melanogaster affect short-term fluctuations in the male's courtship song. Froc. Natl. Acad. Sci. 77: 6729-6733.

Mismer, D. and G.M. Rubin. 1987. Analysis of the promoter of the nina opsin gene in Drosophila melanogaster. Genetics 116: $565-578$.

Mitchison, T.J. and J. Sedat. 1983. Localization of antigenic determinants in whole Drosophila embryos. Dev. Biol. 99: $261-264$.

Page, T.L. 1984. Neuronal organization of a circadian clock in the cockroach Leucophaea maderae. In Photoperiodic regulation of insect and molluscan hormones (eds. R. Porter and G.M. Collins), pp. 115-135. Pitman, London.

Pak, W.L. 1975. Mutants affecting the vision of Drosophila melanogaster. In Handbook of Genetics (ed. R.C. King), vol. 3, pp. 703-733. Plenum, New York.

Phillips, J.P. and H.S. Forrest. 1980. Ommochromes and pteridines. In The genetics and biology of Drosophila (ed. M. Ashburner and T.R.F. Wright), vol. 2, pp. 542-661. Academic Press, London.

Price, J., D. Turner, and C. Cepko. 1987. Lineage analysis in the vertebrate nervous system by retrovirus-mediated gene transfer. Proc. Natl. Acad. Sci. 84: 156-160.

Reddy, P., W.A. Zehring, D.A. Wheeler, V. Pirrotta, C. Hadfield, J.C. Hall, and M. Rosbash. 1984. Molecular analysis of the period locus in Drosophila melanogaster and identification of a transcript involved in biological rhythms. Cell 38: 701710.

Rubin, G.M. 1985. P transposable elements and their use as genetic tools in Drosophila. Trends Neurosci. 8: 231-233.

Saunders, D.S. 1982. Insect clocks, 2nd ed. Pergamon Press, Oxford.

Simon, J.A., C.A. Sutton, R.B. Lobell, R.L. Glaser, and J.T. Lis. 1985. Determinants of heat shock-induced chromosomal puffing. Cell 40: 805-817.

Smith, R.F. and R.J. Kopopka. 1982. Effects of dosage alterations at the per locus on the period of the circadian clock of Drosophila. Mol. Gen. Genet. 189: 30-36.

Strausfeld, N.J. 1976. Atlas of an insect brain. Springer-Verlag, Berlin.

Thomas, J.B., S.T. Crews, and C.S. Goodman. 1988. Molecular genetics of the single-minded locus: A gene involved in the development of the Drosophila nervous system. Cell 52: $133-141$. 
Liu et al.

Truman, J.W. 1985. Rhythmic regulation of eclosion hormone release and action in insects. In Current trends in comparative endocrinology (ed. B. Lofts and W.N. Holmes), pp. 667-669. Hong Kong University Press, Hong Kong.

Weitzel, G. and L. Rensing. 1981. Evidence for cellular circadian rhythms in isolated fluorescent dye-labelled salivary gland of wild type and an arrhythmic mutant of Drosphila melanogaster. J. Comp. Physiol. 143: 229-235.

Wigglesworth, S.V.B. 1970. Insect Hormones. Freeeman, San Francisco.

Williams, D.S. 1982. Rhabdom size and photoreceptor membrane turnover in a muscoid fly. Cell Tiss. Res. 226: 629639.

Wills, S.A., T.L. Page, and C.S. Colwell. 1985. Circadian rhythms in the electroretinogram of a cockroach. $J$. Biol. Rhythms 1: 25-37.

Yanish-Perron, C., J. Vieira, and J. Messing. 1985. Improved M13 phage cloning vectors and host strains: Nucleotide sequences of the M13mpl8 and pUCl9 vectors. Gene 33: $103-119$.

Yu, Q., H.V. Colot, C.P. Kyriacou, J.C. Hall, and M. Rosbash. 1987a. Behaviour modification by in vitro mutagenesis of a variable region within the period gene of Drosophila. $\mathrm{Na}$ ture 326: 765-769.

Yu, Q., A.C. Jacquier, Y. Citri, M. Hamblen, J.C. Hall, and M. Rosbash. 1987b. Molecular mapping of point mutations in the period gene that stop or speed up biological clocks in Drosophila melanogaster. Proc. Natl. Acad. Sci. 84: 784788.

Zehring, W.A., D.A. Wheeler, P. Reddy, R.J. Konopka, C.P. Kyriacou, M. Rosbash, and J.C. Hall. 1984. P-element transformation with period locus DNA restores rhythmicity to mutant, arrhythmic Drosophila melanogaster. Cell 39:369376. 


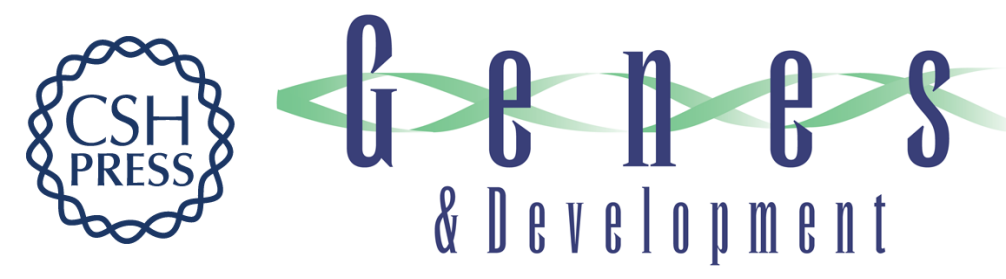

\section{Spatial and temporal expression of the period gene in Drosophila melanogaster.}

X Liu, L Lorenz, Q N Yu, et al.

Genes Dev. 1988, 2:

Access the most recent version at doi:10.1101/gad.2.2.228

References This article cites 38 articles, 7 of which can be accessed free at: http://genesdev.cshlp.org/content/2/2/228.full.html\#ref-list-1

License

Email Alerting

Receive free email alerts when new articles cite this article - sign up in the box at the top Service right corner of the article or click here.

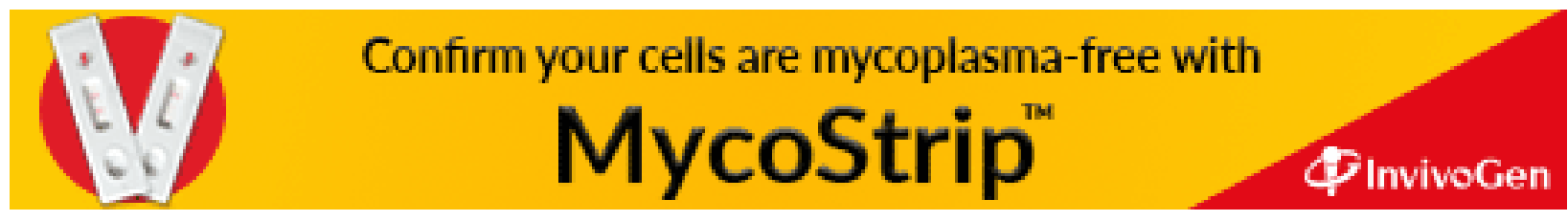

